\title{
Hydric restriction as vigor assessment method of soybean seeds ${ }^{1}$
}

\author{
Denis Santiago da Costa ${ }^{2 *}$, Cartiane Rubishirley Macêdo da Rocha², \\ Ana Dionisia da Luz Coelho Novembre ${ }^{2}$
}

\begin{abstract}
The objective of this study was to investigate the possibility of using hydric restriction as a method for evaluating vigor of soybean seeds. The soybean seeds, cultivar BRS 245RR, represented by four different seed lots, were characterized by germination and vigor. For the treatment of hydric restriction and temperature, the combination of substrate water potential and temperature were the following: deionized water (0.0 MPa); polyethylene glycol (PEG 6000) aqueous solution (-0.1, -0.3 and $-0.5 \mathrm{MPa}$ ); and four temperatures $\left(20^{\circ} \mathrm{C}, 25^{\circ} \mathrm{C}, 30^{\circ} \mathrm{C}\right.$, and $\left.35{ }^{\circ} \mathrm{C}\right)$, respectively. A completely randomized experimental design was used, with four replications per treatment, and the ANOVA was performed individually for each combination of temperature and water potential of substrate. According to results obtained, the test of hydric restriction has the same efficiency of the accelerated aging test in estimating vigor of soybean seeds, cv. BRS 245RR, when water potentials of $-0.1 \mathrm{MPa}$ or $-0.3 \mathrm{MPa}$ at a temperature of $25^{\circ} \mathrm{C}$, or $-0.3 \mathrm{MPa}$ at a temperature of $30^{\circ} \mathrm{C}$ are used.
\end{abstract}

Index term: Glycine max, temperature, PEG6000, physiological potential.

\section{Restrição hídrica como método para a avaliação do vigor em sementes de soja}

\begin{abstract}
RESUMO - Objetivou-se com este trabalho verificar a possibilidade do uso da restrição hídrica como método para a avaliação do vigor em sementes de soja. As sementes de soja, cultivar BRS 245RR, representadas por quatro lotes, foram caracterizadas quanto à germinação e ao vigor. Para os tratamentos de restrição hídrica e temperatura, as combinações de potenciais hídricos do substrato e temperaturas foram as seguintes: água deionizada $(0,0 \mathrm{MPa})$ e soluções aquosas de PEG $6000(-0,1,-0,3$ e - $0,5 \mathrm{MPa})$ e quatro temperaturas de germinação $\left(20^{\circ} \mathrm{C}, 25^{\circ} \mathrm{C}, 30^{\circ} \mathrm{C}\right.$ e $\left.35^{\circ} \mathrm{C}\right)$, respectivamente. $\mathrm{O}$ delineamento experimental foi o inteiramente ao acaso, com quatro repetições e a análise de variância determinada individualmente para cada combinação de temperatura e disponibilidade hídrica do substrato. De acordo com os resultados o teste de restrição hídrica tem a mesma eficiência que o teste de envelhecimento acelerado, para estimar o vigor de sementes de soja, cv BRS 245RR, quando são utilizados os potenciais hídricos de $-0,1 \mathrm{MPa}$ ou $-0,3 \mathrm{MPa}$ à temperatura de $25^{\circ} \mathrm{C}$, ou de $-0,3 \mathrm{MPa}$ à temperatura de $30^{\circ} \mathrm{C}$.
\end{abstract}

Termos para indexação: Glycine max, temperatura, PEG 6000, potencial fisiológico.

\section{Introduction}

The vigor test is an additional alternative tool used by producing companies to implement assessment of seed physiological potential. Seed vigor comprises those proprieties that determine potential for seed germination and seedling emergence in a fast and uniform way under a wide diversity of environmental conditions (AOSA, 1983).

There are nowadays a variety of different tests to estimate seed vigor that are recommended in function of the plant species assessed. According to Vieira et al. (2003), several tests are recommended for assessing vigor of soybean seeds,

\footnotetext{
${ }^{1}$ Submitted on 07/07/2011. Accepted for publication on 09/30/2011.

${ }^{2}$ Departamento de Produção Vegetal - USP/ESALQ, Caixa Postal 9, 13418-900 - Piracicaba, SP, Brasil.

*Corresponding author <denis.esalq@gmail.com>
} 
with emphasis on tests of accelerated aging, tetrazolium, electric conductivity, seedling growth, and classification of seedling vigor. Among the available tests, the accelerated aging is internationally recognized as the most adequate for assessing physiological potential of seeds of various plant species, including soybean, once provides coherent information on seed vigor (TeKrony, 1995). This method has inclusively been standardized by the International Seed Testing Association and since 2001 it is a test whose method is described in the rules for seed analysis of that association. Researchers, however, are constantly evaluating other new technologies to estimate seed vigor and the use of hydric restriction test, during germination process, can be considered as promising in estimating seed vigor as are the test of accelerated aging and the cold test (Silva et al., 2006).

Some researchers have studied influence of hydric availability on germination of soybean seeds. McDonald et al. (1988) have found reduction of soybean seed germination in PEG 6000, starting from osmotic potential of $-0.511 \mathrm{MPa}$. Therefore, the range between 0.0 and -0.5 MPa has potential to estimate soybean seed vigor without reduction on germination, once that, according to Braccini et al. (1998), vigor is more affected than is seed germination when hydric restriction increases.

Notwithstanding, literature results on this matter are still scarce and need further studies. Thus, the objective of this research work was to verify the possible use of hydric restriction as a method for evaluating vigor of soybean seeds.

\section{Material and Methods}

The research work has been carried out at the Seed Analysis Laboratory of the Plant Production Department of the Superior School of Agriculture Luiz de Queiróz, Piracicaba Campus, University of São Paulo (USP/ESALQ), with four lots of seeds of soybean [Glycine max (L.) Merrill], cv. BRS 245RR.

Preliminary tests were performed as follows:

Seed moisture content: this test has been performed with two replications of $10 \pm 1 \mathrm{~g}$ of seeds each, weighed in a $0.001 \mathrm{~g}$ precision analytical balance, and dehydrated by the oven method at $105 \pm 3{ }^{\circ} \mathrm{C}$, for $24 \mathrm{~h}$. After that period, seed samples were again weighed, thus allowing computation of moisture content, in wet basis (Brasil, 2009).

Germination test: 200 seeds were randomly taken from each sample and divided into four replications of 50 seeds each. Seeds of each replication were then arranged on top of two sheets of paper towels, covered with another sheet of the same paper, moistened with sterile distilled water, in an amount equivalent to 2.5 times the mass of dry substrate, made into rolls, and placed into a seed germinator at $25^{\circ} \mathrm{C}$. Assessments were performed at the fifth and eighth day after starting the test, according to Rules for Seed Analysis (RSA) (Brasil, 2009).

Electrical conductivity: four replications of 50 seeds each were used. After drying, seeds were immersed in $75 \mathrm{~mL}$ of distilled water, into plastic cups and then maintained in an incubatoion chamber at $25^{\circ} \mathrm{C}$, for $24 \mathrm{~h}$ (Vieira and Krzyzanowski, 1999). After this period, the electric conductivity of hydration solution was assessed.

Accelerated aging: it was carried out with four replications of 50 seeds each, which were evenly distributed, in a single layer, on top of a stainless screen placed on the upper part of $11 \mathrm{~cm} \times 11 \mathrm{~cm} \times 3.5 \mathrm{~cm}$ transparent plastic boxes (gerbox) containing $40 \mathrm{~mL}$ of sterile distilled water at the bottom. The boxes were then lidded and placed into a seed germinator, at $41{ }^{\circ} \mathrm{C}$, for $48 \mathrm{~h}$ (Marcos-Filho, 1999). After such time span, seeds were assessed by germination test as previously described. Assessment was performed together with the test of first count of germination, at the fifth day after test beginning, according to RSA (Brasil, 2009).

After characterization of moisture content and of physiological potential of seeds from all four lots of seeds, treatments were defined by combining the different water availability of substrate and the temperatures for seed germination. The osmotic solutions were prepared by dissolving polyethylene glycol salt (PEG 6000) aiming at obtaining osmotic potential of $-0.1,-0.3$, and $-0.5 \mathrm{MPa}$. This way, quantities of PEG 6000 needed were computed using the equation proposed by Michel and Kaufmann (1973), which is: $\psi$ os $=-\left(1.18 \times 10^{-2}\right) \mathrm{C}$ - $\left(1.18 \times 10^{-4}\right) \mathrm{C}^{2}+\left(2.67 \times 10^{-4}\right) \mathrm{CT}+\left(8.39 \times 10^{-7}\right) \mathrm{C}^{2} \mathrm{~T}$ in which: $\psi$ os $=$ osmotic potential (bar); $\mathrm{C}=$ concentration (PEG 6000 g. litter distilled $\mathrm{H}_{2} \mathrm{O}^{-1}$ ); and $\mathrm{T}=$ temperature $\left({ }^{\circ} \mathrm{C}\right)$. Once solutions were obtained, 200 seeds were split into four replications of 50 seeds each, which were then placed between sheets of germination paper $\left(\right.$ Germitest $\left.{ }^{\circledR}\right)$ moistened with distilled water (control) or with the different osmotic solutions, in an amount equivalent to 2.5 times the dry mass of paper substrate. Afterwards, the sets (paper + seeds) were placed into seed germinators, at temperatures of $20^{\circ} \mathrm{C}, 25^{\circ} \mathrm{C}, 30^{\circ} \mathrm{C}$, and $35^{\circ} \mathrm{C}$. A single counting was performed, at the fifth day after sowing, considering vigorous only the seeds that produced seedlings with length higher than half the length of the largest normal seedling of each replication. Results were expressed in percentage of seedlings with such characteristics. 
A completely randomized experimental design was used for experiment, with treatments arranged into a $4 \times 4$ factorial scheme (four temperatures $\mathrm{x}$ four osmotic concentrations of substrate). The ANOVA was performed individually for each set of factors (temperature $\mathrm{x}$ osmotic concentration) and treatment means were compared by the Duncan test at $5 \%$ probability. Data were likewise analyzed by Pearson's correlation and $(\mathrm{R})$ values of variables and coherent results were correspondent to those whose associations between hydric availability and temperatures were correlated with at least three tests indicated for vigor assessment of soybean seeds.

\section{Results and Discussion}

Results on characterization of physiological quality of soybean seeds indicated that seeds initially had differences on moisture contents smaller than two percentage points (Table 1), this way interference of moisture content on results of the other tests was eliminated (Marcos-Filho, 2005).

Table 1. Moisture content (MC), germination (G), germination at first count (FCG), accelerated aging (AA), electrical conductivity (EC), seedling length (SL), and dry mass of seedlings (DMS) of four different lots of soybean, cv. BRS 245RR, seeds.

\begin{tabular}{cccccccc}
\hline Seed lots & $\begin{array}{c}\text { MC } \\
(\%)\end{array}$ & $\begin{array}{c}\text { G } \\
(\%)^{*}\end{array}$ & $\begin{array}{c}\text { FCG } \\
(\%)^{*}\end{array}$ & $\begin{array}{c}\text { AA } \\
(\%)^{*}\end{array}$ & $\begin{array}{c}\text { EC } \\
\left(\mu \mathrm{S} . \mathrm{cm}^{-1} \cdot \mathrm{g}^{-1}\right)^{*}\end{array}$ & $\begin{array}{c}\text { SL } \\
(\mathrm{cm})^{*}\end{array}$ & $\begin{array}{c}\text { DMS } \\
\left(\mathrm{g} .10 \mathrm{seedlings}^{-1}\right)^{*}\end{array}$ \\
\hline 1 & 10.9 & $99 \mathrm{a}$ & $98 \mathrm{a}$ & $79 \mathrm{a}$ & $84.9 \mathrm{a}$ & $18.5 \mathrm{a}$ & $0.2974 \mathrm{a}$ \\
2 & 11.2 & $93 \mathrm{~b}$ & $88 \mathrm{~b}$ & $62 \mathrm{~b}$ & $89.3 \mathrm{ab}$ & $14.2 \mathrm{~b}$ & $0.2427 \mathrm{~b}$ \\
3 & 11.5 & $91 \mathrm{~b}$ & $78 \mathrm{c}$ & $40 \mathrm{c}$ & $97.5 \mathrm{~b}$ & $13.5 \mathrm{~b}$ & $0.2406 \mathrm{~b}$ \\
4 & 11.6 & $90 \mathrm{~b}$ & $77 \mathrm{c}$ & $20 \mathrm{~d}$ & $113.07 \mathrm{c}$ & $9.5 \mathrm{c}$ & $0.2133 \mathrm{c}$ \\
\hline $\mathrm{CV}(\%)$ & - & 2.36 & 4.96 & 8.04 & 7.79 & 6.27 & 5.18 \\
\hline
\end{tabular}

*Means followed by the same letter in the columns are not statistically different between each other by the Duncan test at $5 \%$ probability.

Seeds of the four lots have had a percentage of germination higher than that established for commercialization standards (80\%) (Brasil, 2005$)$, and lot 1 has had a percentage of germination statistically higher than the remaining seed lots (Table 1).

Result of assessments for first count of germination showed that lot 1 had the most vigorous seeds, significantly differing from lots 2,3 , and 4 . Lot 2 also showed higher figures than lots 3 and 4 . Between these two last lots, however, statistically significant differences were not found in this test (Table 1).

It was possible to detect statistically significant differences on seed vigor among the four seed lots by the accelerated aging test, and they all differed among each other and from the seed lot 1, the one which had seeds with the best vigor. Results of electrical conductivity test have statistically defined seed quality distinctions only between lots 1 and 2. Among all seed lots assessed, lot 4 has presented the highest quantity of lixiviates (Table 1).

For test of seedling length it was verified that only seed lot 1 has presented plants with higher size than the remaining seed lots. It was not possible to statistically differentiate lots 1 and 2 by this test, but seeds from lot 4 produced plants with the smallest lengths. On assessing seedling dry mass, seed lot 1 surpassed all remaining lots and was thus the seed lot with the most vigorous seeds. Lots 2 and 3 did not statistically differ between each other by this test; and seed lot 4 has had the lowest dry mass of seedlings (Table 1).

Thus, after completion of the physiological potential characterization of seeds for all seed lots, lot 1 was classified as the one with the most vigorous seeds and lot 4 was sorted as the one with seeds having the lowest vigor.

Seeds of the four different lots when subjected to combinations of all four levels of hydric restriction of substrate and four different temperatures have presented reduction on germination and on vigor when the hydric potential of substrate was decreased, with no exceptions and for all the combinations (Tables 2 and 3). Such results reiterate decreases on germination and vigor of soybean seeds when reductions of substrate osmotic potential occur (Braccini et al., 1998; Moraes and Menezes, 2003). 
Table 2. Percentage of soybean seedlings, cv. BRS 245RR, produced by seeds germinated at temperatures of $20^{\circ} \mathrm{C}$ and $35^{\circ} \mathrm{C}$ when correlated to four levels of hydric potential $\left[\Psi_{0}(\mathrm{MPa})\right]$.

\begin{tabular}{cccccccccc}
\hline \multicolumn{2}{c}{ Temperatures } & \multicolumn{9}{c}{$20^{\circ} \mathrm{C}$} & \multicolumn{4}{c}{$35^{\circ} \mathrm{C}$} \\
\hline \multicolumn{2}{c}{$\Psi_{\mathrm{o}}(\mathrm{MPa})$} & $0^{*}$ & $-0.1^{*}$ & $-0.3^{*}$ & $-0.5^{*}$ & $0^{*}$ & $-0.1^{*}$ & $-0.3^{*}$ & $-0.5^{*}$ \\
\hline \multirow{2}{*}{ Seed lots } & 1 & $95.5 \mathrm{a}$ & $91.0 \mathrm{a}$ & $70.5 \mathrm{a}$ & $15.0 \mathrm{a}$ & $75.5 \mathrm{a}$ & $59.5 \mathrm{a}$ & $58.5 \mathrm{a}$ & $16.5 \mathrm{a}$ \\
& 2 & $87.5 \mathrm{~b}$ & $81.5 \mathrm{~b}$ & $36.5 \mathrm{~b}$ & $8.0 \mathrm{~b}$ & $41.0 \mathrm{~b}$ & $36.5 \mathrm{~b}$ & $38.5 \mathrm{~b}$ & $5.0 \mathrm{~b}$ \\
& 3 & $89.0 \mathrm{~b}$ & $83.5 \mathrm{~b}$ & $29.5 \mathrm{~b}$ & $3.0 \mathrm{c}$ & $23.5 \mathrm{c}$ & $16.0 \mathrm{c}$ & $13.0 \mathrm{c}$ & $2.5 \mathrm{c}$ \\
& 4 & $81.5 \mathrm{c}$ & $74.0 \mathrm{c}$ & $22.5 \mathrm{~b}$ & $5.0 \mathrm{bc}$ & $12.5 \mathrm{~d}$ & $12.5 \mathrm{c}$ & $5.0 \mathrm{~d}$ & $2.5 \mathrm{c}$ \\
\hline \multicolumn{2}{c}{$\mathrm{CV}(\%)$} & 6.99 & 3.99 & 12.14 & 14.76 & 11.05 & 6.49 & 14.13 & 14.9 \\
\hline
\end{tabular}

*Means followed by the same letter in the columns are not statistically different between each other by the Duncan test at 5\% probability.

Table 3. Percentage of soybean seedlings, cv. BRS 245RR, produced by seeds germinated at temperatures of $25^{\circ} \mathrm{C}$ and $30^{\circ} \mathrm{C}$ when correlated to four levels of hydric potential $\left[\Psi_{0}(\mathrm{MPa})\right]$.

\begin{tabular}{|c|c|c|c|c|c|c|c|c|c|}
\hline \multicolumn{2}{|c|}{ Temperatures } & \multicolumn{4}{|c|}{$25^{\circ} \mathrm{C}$} & \multicolumn{4}{|c|}{$30^{\circ} \mathrm{C}$} \\
\hline$\Psi_{\mathrm{o}}$ & & $0^{*}$ & $-0.1^{*}$ & $-0.3^{*}$ & $-0.5^{*}$ & $0^{*}$ & $-0.1 *$ & $-0.3 *$ & $-0.5^{*}$ \\
\hline \multirow{4}{*}{ Seed lots } & 1 & $97.0 \mathrm{a}$ & $91.0 \mathrm{a}$ & $87.0 \mathrm{a}$ & $41.5 \mathrm{a}$ & $89.0 \mathrm{a}$ & $91.5 \mathrm{a}$ & $87.0 \mathrm{a}$ & $27.0 \mathrm{a}$ \\
\hline & 2 & $87.5 \mathrm{~b}$ & $83.0 \mathrm{~b}$ & $77.0 \mathrm{~b}$ & $12.0 \mathrm{~b}$ & $86.5 \mathrm{a}$ & $86.0 \mathrm{a}$ & $61.0 \mathrm{~b}$ & $24.0 \mathrm{a}$ \\
\hline & 3 & $77.5 \mathrm{c}$ & $77.5 \mathrm{c}$ & $67.5 \mathrm{c}$ & $12.5 \mathrm{~b}$ & $71.0 \mathrm{~b}$ & $70.5 \mathrm{~b}$ & $58.0 \mathrm{~b}$ & $13.5 \mathrm{~b}$ \\
\hline & 4 & $76.5 \mathrm{c}$ & $69.0 \mathrm{~d}$ & $60.5 \mathrm{~d}$ & $10.0 \mathrm{~b}$ & $57.5 \mathrm{c}$ & $31.5 \mathrm{c}$ & $28.0 \mathrm{c}$ & $8.5 \mathrm{~b}$ \\
\hline \multicolumn{2}{|c|}{ CV(\%) } & 4.98 & 3.36 & 4.58 & 9.37 & 5.56 & 5.49 & 8.82 & 20,62 \\
\hline
\end{tabular}

*Means followed by the same letter in the columns are not statistically different between each other by the Duncan test at $5 \%$ probability.

Under the temperature of $20{ }^{\circ} \mathrm{C}$ during five days normal seedlings were not found, mainly for hydric potentials of $-0.1 \mathrm{MPa},-0.3 \mathrm{MPa}$, and $-0.5 \mathrm{MPa}$, although under such conditions only seeds which have produced plants with primary root already emitted were assessed. Under temperatures of $25^{\circ} \mathrm{C}$ and $30^{\circ} \mathrm{C}$ were found already formed seedlings, making possible detection of quality differences among seed lots (Table 3). The temperature of $35{ }^{\circ} \mathrm{C}$, however, was not suitable for performing this test, due to large amount of contaminant fungi impairing the assessments (Table 2). Development of contaminant fungi were likewise favored by reductions on hydric potential of substrate, once with the use of osmotic potential of $-0.5 \mathrm{MPa}$, higher fungal contamination occurred. Machado et al. (2003) considered that hydric restriction by using solutes such as mannitol, $\mathrm{NaCl}$, and $\mathrm{KCl}$ and hydric potentials between -0.6 and $-1.0 \mathrm{MPa}$ is a procedure which prevents or reduces germination of soybean seeds and is commonly used with such purpose for assessments of sanity of these seeds. The hydric potential of $-0.5 \mathrm{MPa}$ is close to those cited by those authors, thus confirming the results related to seed germination assessments herein performed.
The temperature of $30{ }^{\circ} \mathrm{C}$ associated to hydric potential of $-0.3 \mathrm{MPa}$ were correlated, at $5 \%$ probability, with four vigor tests used to assess physiological quality of soybean seeds (accelerated aging, electric conductivity, length of seedlings, and dry mass of seedlings) (Table 4). The temperature of $25^{\circ} \mathrm{C}$ associated to hydric potential of -0.1 MPa was correlated with tests of electric conductivity and length of seedlings at $5 \%$ probability as well as to accelerated aging test at $1 \%$ probability (Table 4 ). In addition, the temperature of $25{ }^{\circ} \mathrm{C}$ associated to hydric potential of -0.3 $\mathrm{MPa}$ was likewise correlated, at 5\% probability, with the tests of first count of germination and length of seedlings as well as to accelerated aging test, at $1 \%$ probability (Table 4 ).

Combinations of temperatures and hydric potential of substrate $\left(25^{\circ} \mathrm{C}\right.$ at $-0.1 \mathrm{MPa}$; and $25^{\circ} \mathrm{C}$ or $30^{\circ} \mathrm{C}$ at $\left.-0.3 \mathrm{MPa}\right)$ once were correlated with other vigor tests and likewise with the accelerated aging test at $5 \%$ and $1 \%$ probability, indicate the possibility of using this method as a test of vigor to assess physiological quality of soybean seeds (Table 4). Besides, this method has advantages in relation to accelerated aging test or to the test of seed germination, since that it reduces time in obtaining results. For soybean seeds, six to seven days are necessary to assess vigor of 
seeds by the accelerated aging test; or yet, $48 \mathrm{~h}$ of incubation period, at $41{ }^{\circ} \mathrm{C}$ plus four to five days for the process of seed germination to assess seeds by the germination test.

For the method herein proposed only five days are needed.

Table 4. Values of Pearson's correlation coefficient (R) for the combinations of temperatures $\left({ }^{\circ} \mathrm{C}\right)$ and hydric potential of substrate $\Psi_{0}(\mathrm{MPa})$ and their correlation with other tests used to assess physiological quality of soybean seeds, cv. BRS 245RR.

\begin{tabular}{|c|c|c|c|c|c|}
\hline $\begin{array}{l}(\mathrm{R}) \text { among } \\
\text { combinations }\end{array}$ & $\begin{array}{l}\text { First count of } \\
\text { germination }\end{array}$ & Accelerated aging & $\begin{array}{c}\text { Electrical } \\
\text { conductivity }\end{array}$ & Seedling length & $\begin{array}{c}\text { Dry mass of } \\
\text { seedlings }\end{array}$ \\
\hline $20^{\circ} \mathrm{C}$ and $0.0 \mathrm{MPa}$ & $0.8281^{\mathrm{ns}}$ & $0.8918^{\mathrm{ns}}$ & $-0.8863^{\mathrm{ns}}$ & $0.9837 *$ & $0.9713 *$ \\
\hline $20^{\circ} \mathrm{C}$ and $-0.1 \mathrm{MPa}$ & $0.8164^{\mathrm{ns}}$ & $0.8881^{\mathrm{ns}}$ & $-0.8893^{\mathrm{ns}}$ & $0.9818 *$ & $0.9646 *$ \\
\hline $20^{\circ} \mathrm{C}$ and $-0.3 \mathrm{MPa}$ & $0.9542 *$ & $0.8984^{\mathrm{ns}}$ & $-0.7947^{\mathrm{ns}}$ & $0.9347^{\mathrm{ns}}$ & $0.9825 *$ \\
\hline $20{ }^{\circ} \mathrm{C}$ and $-0.5 \mathrm{MPa}$ & $0.9687 *$ & $0.8501^{\mathrm{ns}}$ & $-0.6970^{\mathrm{ns}}$ & $0.8125^{\mathrm{ns}}$ & $0.8777^{\mathrm{ns}}$ \\
\hline $25^{\circ} \mathrm{C}$ and $0.0 \mathrm{MPa}$ & $0.9999 * *$ & $0.9551 *$ & $-0.8540^{\mathrm{ns}}$ & $0.9025^{\mathrm{ns}}$ & $0.9141^{\mathrm{ns}}$ \\
\hline $25^{\circ} \mathrm{C}$ and $-0.1 \mathrm{MPa}$ & $0.9412^{\mathrm{ns}}$ & $0.9933 * *$ & $-0.9688 *$ & $0.9848 *$ & $0.9474^{\mathrm{ns}}$ \\
\hline $25^{\circ} \mathrm{C}$ and $-0.3 \mathrm{MPa}$ & $0.9768 *$ & $0.9945 * *$ & $-0.9416^{\mathrm{ns}}$ & $0.9621 *$ & $0.9395^{\mathrm{ns}}$ \\
\hline $25^{\circ} \mathrm{C}$ and $-0.5 \mathrm{MPa}$ & $0.8758^{\mathrm{ns}}$ & $0.7824^{\mathrm{ns}}$ & $-0.6544^{\mathrm{ns}}$ & $0.8611^{\mathrm{ns}}$ & $0.9490^{\mathrm{ns}}$ \\
\hline $30^{\circ} \mathrm{C}$ and $0.0 \mathrm{MPa}$ & $0.8845^{\mathrm{ns}}$ & $0.9774 *$ & $-0.9848 *$ & $0.9013^{\mathrm{ns}}$ & $0.8154^{\mathrm{ns}}$ \\
\hline $30^{\circ} \mathrm{C}$ and $-0.1 \mathrm{MPa}$ & $0.7902^{\mathrm{ns}}$ & $0.9385^{\mathrm{ns}}$ & $-0.9949 * *$ & $0.9125^{\mathrm{ns}}$ & $0.8066^{\mathrm{ns}}$ \\
\hline $30{ }^{\circ} \mathrm{C}$ and $-0.3 \mathrm{MPa}$ & $0.8771^{\mathrm{ns}}$ & $0.9525^{*}$ & $-0.9510 *$ & $0.9976 *$ & $0.9623 *$ \\
\hline $30{ }^{\circ} \mathrm{C}$ and $-0.5 \mathrm{MPa}$ & $0.9424^{\mathrm{ns}}$ & $0.9871 *$ & $-0.9547 *$ & $0.9004^{\mathrm{ns}}$ & $0.8424^{\mathrm{ns}}$ \\
\hline $35^{\circ} \mathrm{C}$ and $0.0 \mathrm{MPa}$ & $0.9858 *$ & $0.9580 *$ & $-0.8718^{\mathrm{ns}}$ & $0.9547 *$ & $0.9713 *$ \\
\hline $35^{\circ} \mathrm{C}$ and $-0.1 \mathrm{MPa}$ & $0.9995 * *$ & $0.9567 *$ & $-0.8574^{\mathrm{ns}}$ & $0.9158^{\mathrm{ns}}$ & $0.9300^{\mathrm{ns}}$ \\
\hline $35^{\circ} \mathrm{C}$ and $-0.3 \mathrm{MPa}$ & $0.9922 * *$ & $0.9819 *$ & $-0.9066^{\mathrm{ns}}$ & $0.9249^{\mathrm{ns}}$ & $0.9127^{\mathrm{ns}}$ \\
\hline $35^{\circ} \mathrm{C}$ and $-0.5 \mathrm{MPa}$ & $0.9385^{\mathrm{ns}}$ & $0.8392^{\mathrm{ns}}$ & $-0.7045^{\mathrm{ns}}$ & $0.8724^{\mathrm{ns}}$ & $0.9475^{\mathrm{ns}}$ \\
\hline
\end{tabular}

NS $=$ non-significant; $*$ and $* *=$ significant at $5 \%$ and $1 \%$, respectively, by the Duncan test.

The values of hydric potential found in this research are in agreement with those of Braccini et al. (1996) who verified that hydric potentials below $-0.3 \mathrm{MPa}$ are essential to assess vigor of soybean seeds. Oppositely, Silva et al. (2006) have found that when hydric potentials were equal or lower than $-0.6 \mathrm{MPa}$, the sorting of different levels of soybean seed quality was possible. Therefore, results achieved within this research work confirm the non-need of using hydric potentials below -0.3 MPa to assess vigor of soybean seeds.

Consequently, considering results herein obtained as well as results obtained by other researchers, it is indeed possible to use the test of hydric restriction to assess physiological potential of soybean seeds, once results of this test were correlated with results of other tests already established to assess seed vigor, specially the accelerated aging test.

\section{Conclusions}

The test of hydric restriction has the same efficiency of the accelerated aging test to assess vigor of soybean seeds when hydric potentials of $-0.1 \mathrm{MPa}$ or $-0.3 \mathrm{MPa}$, at temperatures of $25^{\circ} \mathrm{C}$ are used; or then when $-0.3 \mathrm{MPa}$ at temperature of $30^{\circ} \mathrm{C}$ are used.

\section{References}

ASSOCIATION OF OFFICIAL SEED ANALYSTS - AOSA. Seed vigor testing handbook. East Lansing: AOSA, 1983. 93p. (Contribution, 32).

BRACCINI, A.L.; REIS, M.S.; SEDIYAMA, C.S.; SEDIYAMA, T.; ROCHA, V.S. Influência do potencial hídrico induzido por polietilenoglicol na qualidade fisiológica de sementes de soja. Pesquisa Agropecuária Brasileira, v.33, n.9, p.1451-1459, 1998. http://webnotes. sct.embrapa.br/pab/pab.nsf/4b9327fca7faccde032564ce004f7a6a/bb224 e33109ed7bf832566be006f4b84/\$FILE/pab379_96.doc

BRACCINI, A.L.; RUIZ, H.A.; BRACCINI, M.C.L.; REIS, M.S. Germinação e vigor de sementes de soja sob estresse hídrico induzido por soluções de cloreto de sódio, manitol e polietilenoglicol. Revista Brasileira de Sementes, v.18, n.1, p.10-16, 1996. http://www.abrates.org. br/revista/artigos/1996/v18n1/artigo03.pdf

BRASIL. Ministério da Agricultura, Pecuária e Abastecimento. Regras 
para análise de sementes. Ministério da Agricultura, Pecuária e Abastecimento. Secretaria de Defesa Agropecuária. Brasília: MAPA/ACS, 2009. 395p.http:// www.agricultura.gov.br/arq_editor/file/Laborat $\% \mathrm{C} 3 \% \mathrm{~B} 3$ rio/Sementes/ Regras\%20para\%20Analise\%20de\%20Sementes.pdf

BRASIL. Instrução normativa n 25, de 16 de dezembro de 2005: Padrão para produção e comercialização de sementes de soja. Diário Oficial da União, n. 243, Brasília, DF, 2005. Seção 1, p.2.

MACHADO, J.C.; OLIVEIRA, J.A.; VIEIRA, M.G.G.C.; ALVES, M.C. Controle da germinação de sementes de soja em testes de sanidade pelo uso da restrição hídrica. Revista Brasileira de Sementes, v.25, n.2, p.7781, 2003. http://www.scielo.br/pdf/rbs/v25n2/19652.pdf

MARCOS-FILHO, J. Fisiologia de sementes de plantas cultivadas. Piracicaba: FEALQ, 2005. 495p.

MARCOS-FILHO, J. Teste de envelhecimento acelerado. In: KRZYZANOWSKI, F.C.; VIEIRA, R.D.; FRANÇA NETO, J.B. (Ed.). Vigor de sementes: conceitos e testes. Londrina: ABRATES, 1999. cap.3, p.3.1-3.24.

McDONALD, M.B.; VERTUCCI, C.W.; ROOS, E.E. Soybean seed imbibition: water absorption by seed parts. Crop Science, v.28, n.6, p.993-997, 1988.
MICHEL, B.E.; KAUFMANN, M.R. The osmotic potencial of polytylene glycol 6000. Plant Physiology, p.914-916, 1973. http://www.ncbi.nlm. nih.gov/pmc/articles/PMC366375/pdf/plntphys00228-0098.pdf

MORAES, G.A.F.; MENEZES, N.L. Desempenho de sementes de soja sob condições diferentes de potencial osmótico. Ciência Rural, v.33, n.2, p.219-226, 2003. http://www.scielo.br/pdf/cr/v33n2/15209.pdf

SILVA, J.B.; RODRIGUES, T.J.D.; VIEIRA, R.D. Desempenho de sementes de soja submetida a diferentes potenciais osmóticos em polietilenoglicol. Ciência Rural, v.23, n5, p.1634-1637, 2006. http:// www.scielo.br/pdf/cr/v36n5/a47v36n5.pdf

TEKRONY, D.M. Accelerated aging test. In: HAMPTON, J.G. e TEKRONY, D.M. (Ed.) Handbook of vigour test methods. 3.ed. Zurich: International Seed Testing Association, 1995. p.35-50.

VIEIRA, R.D.; KRZYZANOWSKI, F.C. Teste de condutividade elétrica. In: KRZYZANOWSKI, F.C.; VIEIRA, R.D.; FRANÇA NETO, J.B. (Ed.) Vigor de sementes: conceitos e testes. Londrina: ABRATES, 1999. cap.4, p.1-26

VIEIRA, R.D.; BITTENCOURT, S.R.M.; PANOBIANCO, M. Seed vigour - an important component of seed quality in Brazil. ISTA - Seed Testing International, n.126, p.21-22, 2003. 